\title{
Trihoney Suppresses Soluble Adhesion Molecules (ICAM-1 and VCAM-1) in Hypercholesterolemic Atherosclerotic Rabbits: A Comparative Study with Atorvastatin
}

(Trihoney Menekan Molekul Pelekatan Larut (ICAM-1 dan VCAM-1) pada Arnab Aterosklerotik Hiperkolesterolemik: Kajian Perbandingan dengan Atorvastatin)

Hamad Abdul Salam Hamad Alfarisi, Muhammad Ibrahim*, Zenab B. Hamad Mohamed, Asmah hanim HAMDAN \& CHE ANUAR CHE MOHAMAD

\begin{abstract}
Atherosclerosis is a chronic inflammatory disease and high serum cholesterol proven as the main trigger of its pathogenesis. Development of atherosclerotic lesions is closely related to the level of serum cholesterol. Expression of adhesion molecules has been correlated with the extent of aortic lesions. Serum circulating forms of intercellular adhesion molecule-1 (ICAM-1) and vascular cell adhesion molecule-1 (VCAM-1) have been detected in high levels in vascular inflammatory diseases. Honey has been shown to diminish the expression of VCAM-1 in vascular endothelium. Thirty-six male New Zealand white (NZW) rabbits were grouped into: normal diet $(\mathrm{C})$, normal diet with $0.6 \mathrm{~g} / \mathrm{kg} /$ day of Trihoney $(\mathrm{C}+\mathrm{H}), 1 \%$ cholesterol diet $(\mathrm{HCD}), 1 \%$ cholesterol diet with $0.3 \mathrm{~g} / \mathrm{kg} /$ day of Trihoney $\left(\mathrm{HCD}+\mathrm{H}_{\mathrm{p}}\right), 1 \%$ cholesterol diet with $0.6 \mathrm{~g} / \mathrm{kg} /$ day of Trihoney $\left(\mathrm{HCD}+\mathrm{H}_{2}\right)$ and $1 \%$ cholesterol diet with $2 \mathrm{mg} / \mathrm{kg} /$ day of atorvastatin $(H C D+A t)$. Animals were sacrificed after 12 weeks of treatment. Serum was analysed for lipids, ICAM-1 and VCAM-1. Atherosclerotic plaques in the aorta were quantified. Serum ICAM-1 and VCAM-1 were significantly elevated in the HCD group when compared to the control groups. Groups Supplemented with Trihoney showed a significant suppression of serum ICAM-1 and VCAM-1 in comparison to the HCD group. Serum ICAM-1 and VCAM-1 exhibited a significant positive correlation with serum cholesterol. Serum VCAM-1 showed a significant positive correlation with the percentage of aortic lesions. Results of this study showed that Trihoney has anti-atherosclerotic potential through suppression of adhesion molecules. Trihoney was comparable to atorvastatin and may be suggested as an adjuvant remedy for protection against atherosclerosis.
\end{abstract}

Keywords: Adhesion molecules; atorvastatin; cholesterol; Trihoney

\section{ABSTRAK}

Aterosklerosis adalah penyakit keradangan kronik dan kolesterol serum yang tinggi terbukti sebagai pencetus utama patogenesisnya. Perkembangan lesi aterosklerotik berkait rapat dengan tahap kolesterol serum. Ekspresi molekul lekatan telah berkorelasi dengan sejauh mana lesi aorta. Bentuk peredaran serum molekul lekatan antara sel (1 ICAM1) dan molekul lekatan sel vaskular-1 (VCAM-1) telah dikesan pada tahap tinggi dalam penyakit radang vaskular. Madu terbukti dapat mengurangkan ekspresi VCAM-1 pada endotelium vaskular. Tiga puluh enam ekor arnab putih New Zealand $(\mathrm{NZW})$ dikelompokkan kepada: diet normal $(\mathrm{C})$, diet normal dengan $0.6 \mathrm{~g} / \mathrm{kg} /$ day Trihoney $(\mathrm{C}+\mathrm{H})$, $1 \%$ diet kolesterol (HCD), 1\% kolesterol diet dengan $0.3 \mathrm{~g} / \mathrm{kg} /$ day Trihoney $\left(\mathrm{HCD}+\mathrm{H}_{\mathrm{p}}\right)$, $1 \%$ diet kolesterol dengan $0.6 \mathrm{~g} / \mathrm{kg} /$ day Trihoney $\left(\mathrm{HCD}+\mathrm{H}_{2}\right)$ dan 1\%diet kolesterol dengan $2 \mathrm{mg} / \mathrm{kg} /$ day atorvastatin $(\mathrm{HCD}+\mathrm{At})$. Haiwan dikorbankan setelah 12 minggu rawatan. Serum dianalisis untuk lipid, ICAM-1 dan VCAM-1. Plak aterosklerotik di aorta diukur. Serum ICAM-1 dan VCAM-1 meningkat secara signifikan dalam kumpulan HCD jika dibandingkan dengan kumpulan kawalan. Kumpulan yang diberi Trihoney menunjukkan penekanan serum ICAM-1 dan VCAM-1 yang signifikan berbanding dengan kumpulan HCD. Serum ICAM-1 dan VCAM-1 menunjukkan korelasi positifyang signifikan dengan kolesterol serum. Serum VCAM-1 menunjukkan korelasi positif yang signifikan dengan peratusan lesi aorta. Hasil kajian ini menunjukkan bahawa Trihoney mempunyai potensi anti-aterosklerotik melalui penekanan molekul lekatan. Trihoney setanding dengan atorvastatin dan boleh disarankan sebagai ubat tambahan untuk perlindungan terhadap aterosklerosis.

Kata kunci: Atorvastatin; kolesterol; molekul lekatan; Trihoney 


\section{INTRODUCTION}

Atherosclerosis is a disease of tunica intima of large and medium sized arteries (Lorkowski et al. 2007). High serum cholesterol proven as one of the main pathogenic triggers of atherosclerosis (Bergheanu et al. 2017). The histopathological lesion of atherosclerosis is called as plaque (Moore et al. 2011). The pathological hallmark of the atherosclerotic plaque is the foam cells, which are macrophages loaded with cytoplasmic fatty droplets (Patel et al. 2015). Recently, hypercholesterolemia has been considered as a direct cause of endothelial dysfunction (Bergheanu et al. 2017). Development of atherosclerotic lesions is closely related to the level of serum cholesterol (Yu et al. 2012). With more impact exerted by low-density lipoprotein cholesterol (LDL-c) (Bergheanu et al. 2017). Expression of adhesion molecules has been correlated with the extent of aortic lesions (Fotis et al. 2012). Experimental rabbits fed high cholesterol diet not only showed over expression of ICAM-1 in aorta and coronary arteries, but also in choroid plexus and scleral vessels of the eyes, which indicates the wide vascular over expression of ICAM-1 due to hypercholesterolemia (de Almeida Torres et al. 2014). Inflammatory markers and adhesion molecules related to progression of atherosclerotic plaque such as: TNF- $\alpha$ (Boesten et al. 2005), ICAM-1, and VCAM-1 have been found to be upregulated and over expressed in atherosclerotic lesions (Randolph 2014). Cellular adhesion molecules are glycoprotein molecules traversing cell membrane of many cells and expressed on cell surface, they mediate cell-to-cell and cell-matrix interactions (Hope et al. 2003). Endothelial cell adhesion molecules have been suggested to have a pathological and clinical outcomes in atherosclerosis because they facilitate the emigration of inflammatory leucocytes into the vessel walls, a characteristic pathological feature of atherosclerotic plaque formation (Oikonomou et al. 2018). Soluble serum circulating forms as well as locally expressed ICAM-1 and VCAM-1 have been detected in high levels in vascular inflammatory diseases such as peripheral artery diseases and acute coronary syndrome (Tousoulis et al. 2001). Furthermore, they found to be associated with increased cardiovascular risk (Brevetti et al. 2006; Du et al. 2013). Management of atherosclerosis by the conventional medicines is not devoid of serious side effects in addition to burden of economic expenses. Natural products such as honey demonstrated safety and health benefits. Honey demonstrated anti-inflammatory effect by reducing inflammatory markers such as: TNF- $\alpha$ (Majtanova et al. 2016). Moreover, honey has been shown to diminish TNF- $\alpha$ induced expression of VCAM-1 in vascular endothelium indicating that honey may has antiatherogenic property (Spilioti et al. 2014). Trihoney is a natural product made of a combination of three types of honey namely: Trigona, mellifera, and Dorsata. This product was made at the Department of Nutrition Sciences laboratories, Kulliyyah of Allied Health Sciences, International Islamic University Malaysia (IIUM). The combination ratio was 45,15 , and 10 of the mentioned honeys, respectively, and it was determined by Design Expert Version 6.0 software and Response Surface Methodology (RSM) looking for a combination formula having the maximum total phenolic content (TPC). Moreover, Trihoney had high concentrations of phenolic compounds such as: Quercetin, Kaempferol, Rutin, Catechin, Maleic acid, Caffeic acid, Cinnamic acid, Coumaric acid, Gallic acid, p-Hydroxybenzoic acid, Salicylic acid, Sinapic acid, and Vanillic acid. Additionally, Trihoney has antioxidant properties. This combination suggested to provide synergistic effects between honey types with regard to the anti-inflammatory and immunomodulatory functions. The possible mechanisms by which Trihoney may suppress the adhesion molecules are through the lipid lowering effect, the anti-inflammatory function, and the antioxidant effects. All these protective functions can contribute to the suppression of adhesion molecules (ICAM-1 and VCAM1) and consequently may explain the anti-atherogenic effects of Trihoney against atherosclerosis. Current study aims to explore the anti-atherosclerotic potential of Trihoney against expression of vascular adhesion molecules in a comparison to atorvastatin. Atorvastatin is a famous example of statins. Statins are the classical lipid lowering agents they are very popular in medical practice and efficient in lowering serum lipids (Catapano et al. 2016). It can reduce serum LDL-c by $21-55 \%$ (Jellinger et al. 2017; Rahman et al. 2017). Atorvastatin is a widely used statin for prevention of atherosclerosis by its lipid lowering effect through inhibiting the HMG-CoA reductase enzyme (rate-limiting enzyme in cholesterol synthesis) (Zhou et al. 2010). Despite that, atorvastatin has side effects such as myopathy and raised liver enzymes (Jellinger et al. 2017). One of the aims of the current work was to introduce Trihoney as a natural product to be a future adjuvant remedy for management of atherosclerosis. This approach of combining natural products with the classical pharmacotherapies will reduce the required doses of such drugs, hence minimises their side effects. Moreover, this combination approach will provide the treated subjects with the pleiotropic effects of the natural products.

\section{MATERIALS AND METHODS}

\section{CHEMICALS, REAGENTS AND ASSAY KITS}

Pure cholesterol powder Nacalai-Tesque (Kyoto, Japan). Cholesterol-free extra virgin coconut oil (Philippines). Rabbit intercellular adhesion molecule 1, ICAM-1/ CD54 ELISA Kit, (Cusabio, China). Rabbit Vascular cell adhesion molecule 1, VCAM-1 ELISA kit, (Cusabio, China). 
TRIHONEY AND ATORVASTATIN

Trihoney is a product made in Department of Nutrition Sciences, Kulliyyah of Allied Health Sciences, International Islamic University Malaysia (IIUM). Trihoney is a combination of three types of honey: Trigona, Mellifera, and Dorsata, at ratios of 45, 15, and 10, respectively. Trihoney was administered to the respective animal groups by oral route. Two doses have been used $\left(0.3\right.$ and $\left.0.6, \mathrm{~g} \mathrm{~kg}^{-1} \mathrm{day}^{-1}\right)$. Doses have been calculated based on human and rabbit $\mathrm{K}_{m}$ factors according to Reagan-Shaw et al. (2007). $\mathrm{K}_{m}$ factor is a constant calculated based on normalisation of body surface area for accurate translation of drug doses between mammalian species. Trihoney doses have been calculated according to the following equation: (Human equivalent dose $\times$ Human $\mathrm{K}_{m}$ factor $=$ Animal equivalent dose $\times$ Animal $\mathrm{K}_{m}$ factor), with the adult human $\mathrm{K}_{m}$ factor is 37 and the rabbit $\mathrm{K}_{m}$ factor is 12. Atorvastatin $40 \mathrm{mg}$ film-coated tablets (Prague-Czech) were crushed into fine powder, reconstituted in $1 \mathrm{~mL}$ of distilled water and given by oral gavage using clean syringe ( $\mathrm{Du}$ et al. 2013; Jorge et al. 2005; Song et al. 2014), at a dose of 2 $\mathrm{mg} \mathrm{kg}^{-1}$ body weight.

\section{PREPARATION OF 1\% CHOLESTEROL DIET}

Preparation of $1 \%$ cholesterol diet was performed according to Jorge et al. (2005) with some modification as follows: $40 \mathrm{~g}$ of pure cholesterol powder (NacalaiTesque, Kyoto, Japan) was emulsified in $80 \mathrm{~mL}(=80 \mathrm{~g})$ of cholesterol-free extra virgin coconut oil (product of Philippines). The cholesterol emulsion evenly poured over $3380 \mathrm{~g}$ of standard rabbit pellets (Perternakan Hong Lee Sdn. Bhd., Malaysia). The prepared food (1\% cholesterol, $2 \%$ coconut oil rabbit pellet) then packed in zipped bags and kept at temperature of $20-22{ }^{\circ} \mathrm{C}$ for use.

\section{ANIMAL}

Thirty-six NZW rabbits of male gender were purchased from certified experimental animal supplier (A Sapphire Enterprise, Seri Kembangan, Selangor, Malaysia), animal weight ranged from 2 to $2.5 \mathrm{~kg}$, and animal's age 20 weeks. Animals were randomly housed in stainlesssteel cages designed for rabbits as a single rabbit per cage with free access to water and standard rabbits' pellet. Animals were housed with care according to the guidelines of Malaysian Code of Practice for the Care and Use of Animals for Scientific Purposes (AEPC) (AEPC 2012), and the protocol of this experiment was approved by the Institutional Animal Care and Use Committee of International Islamic University Malaysia (IACUCIIUM) with ID approval (IIUM/IACUC- Approval /2017 (19)).

\section{EXPERIMENTAL STUDY}

Thirty-six male NZW rabbits were grouped into the following 6 groups: normal diet $(\mathrm{C})$, normal diet with Trihoney dose of $0.6 \mathrm{~g} \mathrm{~kg}^{-1}$ day $^{-1}(\mathrm{C}+\mathrm{H}), 1 \%$ cholesterol diet (HCD), $1 \%$ cholesterol diet with $0.3 \mathrm{~g} \mathrm{~kg}^{-1}$ day $^{-1}$ of Trihoney $\left(\mathrm{HCD}+\mathrm{H}_{1}\right), 1 \%$ cholesterol diet with $0.6 \mathrm{~g} \mathrm{~kg}^{-1}$ day $^{-1}$ of Trihoney $\left(\mathrm{HCD}+\mathrm{H}_{2}\right)$ and $1 \%$ cholesterol diet with $2 \mathrm{mg} \mathrm{kg}^{-1} \mathrm{day}^{-1}$ of atorvastatin (HCD+At). At the end of 12 weeks, animals anaesthetised by a combination of ketamine and xylasine given through intramuscular route (de Almeida Torres et al. 2014) at doses of 50 and 10 $\mathrm{mg} \mathrm{kg}^{-1}$, respectively (Bolayirli et al. 2007). Blood was withdrawn from central ear artery (Bolayirli et al. 2007).

\section{SERUM PREPARATION AND PARAMETERS ANALYSIS}

Blood were collected from the animals into plain tubes, allowed to clot at room temperature for 40 min (Brown 2016), and then centrifuged (Centrifuge Universal 320R Hettich, Germany) at $4{ }^{\circ} \mathrm{C}$ by speed of $3500 \mathrm{rpm}$, for 15 min (Sukardi et al. 2005; Thon et al. 2012). The collected sera immediately analysed for lipid profile by automated analysis machine (Au480 Au Analyser-Beckman Coulter, Inc.). Serum LDL-c was calculated according to Friedewald's equation: $(L D L-c=T C-H D L-c-(T G / 5)$ $\mathrm{mmol} / \mathrm{L}$ ) (Friedewald et al. 1972). Analysis of serum ICAM-1 and VCAM-1 was performed by ELISA technique according to the manufacturer's protocol.

\section{MEASUREMENT OF AORTIC LESION AREA PERCENTAGE}

After animal sacrificing, aorta was dissected and then transferred to smooth surface dish containing iced-cold PBS and opened longitudinally up to the right common iliac artery and then pinned (Mohanta et al. 2016). Sudan IV staining was employed according to Fan et al. (2001) protocol. Sudan IV stained the atherosclerotic plaques red while other non-plaque containing areas stained pale. Image with a digital camera was taken for the whole stained aorta. The quantification of the atherosclerotic lesions carried out by use of a computerized image analysis system (Image J software 1.52a National Institute of Health USA) measuring the sudanophilic lesion areas relative to the total photographed surface area of the aorta and expressed as a percentage to the whole aorta, according to the following formula (Percentage $(\%)$ lesion area $=($ Area of the lesion/Total aortic area $)$ $\times 100 \%$ ) (Ibrahim et al. 2017).

\section{STATISTICAL ANALYSIS}

Statistical Package for Social Sciences (SPSS version 21 Chicago, Illinois, USA) software was used for data processing. Data were expressed as mean (M) 
and standard deviation (SD) and analysed by oneway analysis of variance (ANOVA). One-way ANOVA followed by Post Hoc test used for determination of any significant differences between means of two or more independent groups. Statistical significance considered at $p<0.05$. Correlation between ICAM-1, VCAM-1, and serum lipid profile and correlation between VCAM-1 and aortic lesion area percentage were investigated using Pearson's correlation coefficients $(r)$ and the statistical significance was considered at $p<0.05$.

\section{RESULTS AND DISCUSSION}

EFFECTS OF TRIHONEY AND $1 \%$ CHOLESTEROL DIET ON SERUM INTERCELLULAR ADHESION MOLECULE-1 (ICAM-1) AND VASCULAR CELL ADHESION MOLECULE-1 (VCAM-1)

Effects of Trihoney and 1\% cholesterol diet on serum ICAM- 1 and VCAM- 1 are summarised in Tables 1 and 2. Rabbits received 1\% cholesterol diet alone (HCD) for 12 weeks' duration showed significant $(p<0.05)$ elevation of serum ICAM-1 and VCAM-1 when compared to the control groups $(\mathrm{C}$ and $\mathrm{C}+\mathrm{H})$. Treatment group $\left(\mathrm{HCD}+\mathrm{H}_{1}\right)$ which received Trihoney simultaneously with $1 \%$ cholesterol diet had a significant $(p<0.05)$ reduction in serum ICAM-1 when compared to the HCD group. Similarly, experimental group received 1\% cholesterol diet accompanied with atorvastatin showed significant $(p<0.05)$ reduction in serum ICAM-1 when compared to the HCD group. All treatment groups that received either Trihoney or atorvastatin exhibited no significant difference in serum ICAM-1 when compared to the control groups. Moreover, Trihoney treated groups $\left(\mathrm{HCD}+\mathrm{H}_{1}\right.$ and $\mathrm{HCD}+\mathrm{H}_{2}$ ) had significantly reduced serum VCAM-1 level compared to the HCD group. Treatment group that received atorvastatin $(\mathrm{HCD}+\mathrm{At})$ showed no significant reduction in serum VCAM-1 in comparison to the HCD group despite it had a lower mean value than the HCD group. However, this group exhibited no significant difference from the control group. On the contrary, the $\mathrm{HCD}+$ At group showed a significant $(p<0.05)$ increase in serum VCAM-1 level when compared to the $\mathrm{C}+\mathrm{H}$ group.

TABLE 1. Effect of Trihoney and 1\% cholesterol diet on serum intercellular adhesion molecule-1 (ICAM-1) at week 12

\begin{tabular}{|c|c|}
\hline Group & Serum ICAM-1 $\left(\mathrm{ng} \mathrm{mL}^{-1}\right)$ \\
\hline $\mathrm{C}$ & $0.50 \pm 0.031^{\mathrm{a}}$ \\
\hline $\mathrm{C}+\mathrm{H}$ & $0.50 \pm 0.07^{\mathrm{a}}$ \\
\hline $\mathrm{HCD}$ & $0.72 \pm 0.12^{\mathrm{b}}$ \\
\hline $\mathrm{HCD}+\mathrm{H}_{1}$ & $0.52 \pm 0.05^{\mathrm{a}}$ \\
\hline $\mathrm{HCD}+\mathrm{H}_{2}$ & $0.64 \pm 0.11^{\mathrm{a}}$ \\
\hline $\mathrm{HCD}+$ At. & $0.52 \pm 0.05^{\mathrm{a}}$ \\
\hline
\end{tabular}

Values are mean \pm standard deviation (SD) of the mean. The results of all experiment groups were analysed using one-way analysis of variance (ANOVA), followed by Tukey HSD Post Hoc test. a,b Values not sharing a common superscript letter differ significantly at $p<0.05$. C $=$ Control

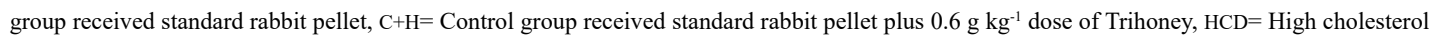
diet group received $1 \%$ cholesterol diet only, $\mathrm{HCD}+\mathrm{H}_{1}$ and $\mathrm{HCD}+\mathrm{H}_{2}$ groups received $1 \%$ cholesterol diet plus 0.3 and $0.6 \mathrm{~g} \mathrm{~kg}^{-1}$ dose of Trihoney, respectively, $\mathrm{HCD}+\mathrm{At}=$ group received $1 \%$ cholesterol diet plus $2 \mathrm{mg} \mathrm{kg}^{-1}$ dose of atorvastatin 
TABLE 2. Effect of Trihoney and $1 \%$ cholesterol diet on serum vascular cell adhesion molecule ${ }^{-1}$ $\left(\mathrm{VCAM}^{-1}\right)$ at week 12

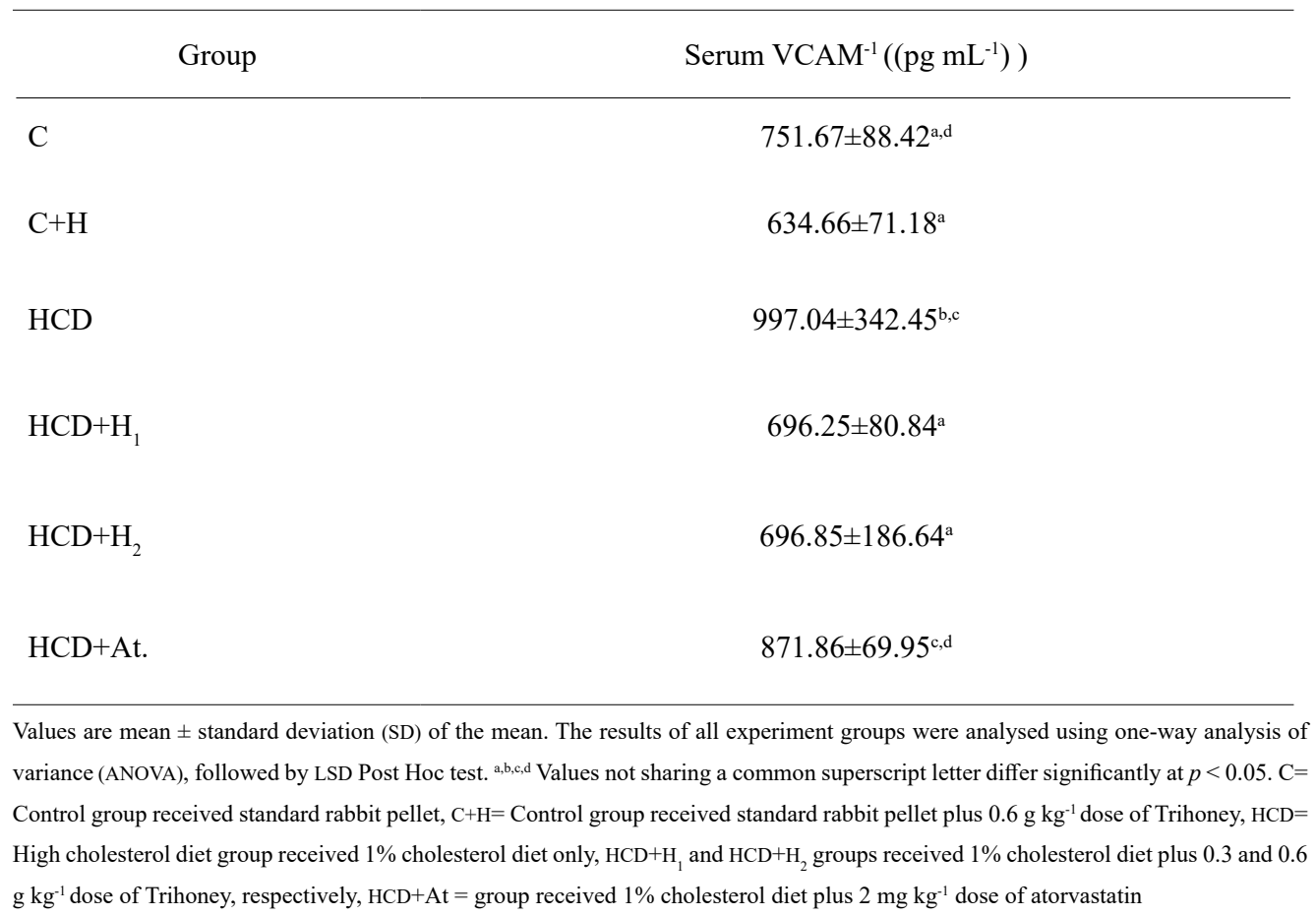

Cellular adhesion molecules are transmembrane glycoproteins immunoglobulins superfamily expressed on surface of vascular endothelium and on many other cells (Brevetti et al. 2006). Expression of cellular adhesion molecules on the surface of endothelial cells in lesions prone areas under influence of inflammatory cytokines and oxidised LDL (Ox-LDL) has been described as a key step in the pathogenesis of atherosclerosis (Fotis et al. 2012; Wu et al. 2017). The multi-step process of leukocytes, rolling, adhesion, and transmigration through the vascular endothelium is almost dependent on endothelial expression of ICAM-1 and VCAM-1 and of course recognition of these immunoglobulins by counter receptors on leukocytes (Hansson 2005). Both ICAM1 and VCAM-1 have been detected in the serum and interpreted with the pathogenesis of the cardiovascular diseases (Tousoulis et al. 2001). Soluble serum circulating forms as well as locally expressed ICAM-1 and VCAM-1 have been detected in high levels in vascular inflammatory diseases such as peripheral artery diseases, moreover they found to be associated with increased cardiovascular risk (Brevetti et al. 2006; Du et al. 2013). The present study has demonstrated that, $1 \%$ cholesterol diet successfully induced hypercholesterolemic status (Table 3) as well as extensive atherosclerotic plaque lesions in the aorta (Table 4) accompanied with elevation in the serum level of soluble adhesion molecules ICAM1 and VCAM-1 as has been described (Tables $1 \& 2$ ). This is very consistent with other experimental studies reported increased vascular expression of ICAM-1 and VCAM-1 in addition to elevation of their serum level under hypercholesterolemic status (de Almeida Torres et al. 2014; Du et al. 2013; Fotis et al. 2012; Kong et al. 2013; Li et al. 1993; Mikail 2015; Ohta et al. 2005). The current investigation showed the effective lipid lowering effect of Trihoney as well as the protective function of Trihoney against the atherosclerotic plaques. Furthermore, Trihoney exhibited reducing effect on the adhesion molecules which are well known crucial key factors for pathogenesis of atherosclerosis.

Furthermore, this investigation showed significant positive correlation between serum lipid profile and serum levels of ICAM-1 and VCAM-1 (Table 5). The relationship between hypercholesterolemia and these adhesion molecules could be cause and effect relationship. Moreover, this study reported significant positive correlation between elevated serum VCAM-1 and the percentage of atherosclerotic lesions in the aorta (Table 6). At one end this correlation may interconnect hypercholesterolemia with these adhesion molecules 
TABLE 3. Baseline and week 12 serum total cholesterol (TC) and serum low-density lipoprotein cholesterol (LDL-c)

\section{Parameter}

\begin{tabular}{|c|c|c|c|c|}
\hline \multirow{2}{*}{ Groups } & $\mathrm{TC}\left(\mathrm{mmol} \mathrm{L}^{-1}\right)$ & $\mathrm{TC}\left(\mathrm{mmol} \mathrm{L}^{-1}\right)$ Week & LDL-c $\left(\mathrm{mmol} \mathrm{L}^{-1}\right)$ & LDL-c $\left(\mathrm{mmol} \mathrm{L}^{-1}\right)$ Week \\
\hline & Baseline & 12 & Baseline & 12 \\
\hline $\mathrm{C}$ & $1.16 \pm 0.51^{\mathrm{a}}$ & $0.48 \pm 0.71^{\mathrm{a}}$ & $0.30 \pm 0.34^{\mathrm{a}}$ & $0.14 \pm 0.34^{\mathrm{a}}$ \\
\hline $\mathrm{C}+\mathrm{H}$ & $1.34 \pm 0.56^{\mathrm{a}}$ & $1.13 \pm 0.78^{\mathrm{a}}$ & $0.51 \pm 0.42^{\mathrm{a}}$ & $0.41 \pm 0.65^{\mathrm{a}}$ \\
\hline $\mathrm{HCD}$ & $1.35 \pm 0.58^{\mathrm{a}}$ & $46.19 \pm 5.67^{\mathrm{b}}$ & $0.58 \pm 0.38^{\mathrm{a}}$ & $37.59 \pm 6.87^{\mathrm{b}}$ \\
\hline $\mathrm{HCD}+\mathrm{H}_{1}$ & $1.45 \pm 0.71^{\mathrm{a}}$ & $35.44 \pm 4.21^{\mathrm{c}}$ & $0.54 \pm 0.60^{\mathrm{a}}$ & $26.47 \pm 5.53^{\mathrm{c}}$ \\
\hline $\mathrm{HCD}+\mathrm{H}_{2}$ & $1.69 \pm 0.62^{\mathrm{a}}$ & $35.45 \pm 5.98^{c}$ & $0.56 \pm 0.47^{\mathrm{a}}$ & $23.11 \pm 8.26^{\mathrm{c}}$ \\
\hline $\mathrm{HCD}+\mathrm{At}$ & $2.24 \pm 1.11^{\mathrm{a}}$ & $37.35 \pm 2.36^{\mathrm{c}}$ & $1.11 \pm 1.10^{\mathrm{a}}$ & $27.17 \pm 6.39^{c}$ \\
\hline
\end{tabular}

Values are mean \pm standard deviation (SD) of the mean. The results of all experiment groups were analysed using one-way analysis of variance (ANOVA), followed by Tukey HSD Post Hoc test. Mean difference is considered significant at $(p<0.05)$. a,b,c Values not sharing a common superscript letter within the same column differ significantly at $p<0.05 . \mathrm{C}=\mathrm{Control}$ group received standard rabbit pellet, $\mathrm{C}+\mathrm{H}=\mathrm{Control}$ group received standard rabbit pellet plus $0.6 \mathrm{~g} \mathrm{~kg}^{-1} \mathrm{dose}$ of Trihoney, $\mathrm{HCD}=\mathrm{High}$ cholesterol diet group received $1 \%$ cholesterol diet only, $\mathrm{HCD}+\mathrm{H}_{1}$ and $\mathrm{HCD}+\mathrm{H}_{2}$ groups received $1 \%$ cholesterol diet plus 0.3 and $0.6 \mathrm{~g} \mathrm{~kg}^{-1}$ dose of Trihoney, respectively, $\mathrm{HCD}+\mathrm{At}=$ group received $1 \%$ cholesterol diet plus $2 \mathrm{mg} \mathrm{kg}^{-1}$ dose of atorvastatin

TABLE 4. Percentage of atherosclerotic aortic lesions

\begin{tabular}{lc}
\hline \multicolumn{1}{c}{ Group } & Aortic lesion area percentage (\%) \\
\hline $\mathrm{C}$ & $0.03 \pm 0.02^{\mathrm{a}}$ \\
$\mathrm{C}+\mathrm{H}$ & $0.00 \pm 0.00^{\mathrm{a}}$ \\
$\mathrm{HCD}$ & $76.09 \pm 6.66^{\mathrm{b}}$ \\
$\mathrm{HCD}+\mathrm{H}_{1}$ & $44.77 \pm 14.47^{\mathrm{c}, \mathrm{d}}$ \\
$\mathrm{HCD}+\mathrm{H}_{2}$ & $14.30 \pm 6.88^{\mathrm{a}, \mathrm{d}}$ \\
$\mathrm{HCD}+\mathrm{At}$ & $29.11 \pm 18.23^{\mathrm{d}}$ \\
\hline
\end{tabular}

Values are mean \pm standard deviation (SD) of the mean. The results of all experiment groups were analysed using one-way analysis of variance (ANOVA), followed by Tukey HSD Post Hoc test. Mean difference is considered significant at $(p<0.05)$. a,b,c,d Values not sharing a common superscript letter within the same column differ significantly at $p<0.05$. $\mathrm{C}=\mathrm{Control}$ group received standard rabbit pellet, $\mathrm{C}+\mathrm{H}=\mathrm{C}$ Control group received standard rabbit pellet plus $0.6 \mathrm{~g} \mathrm{~kg}^{-1}$ dose of Trihoney, $\mathrm{HCD}=$ High cholesterol diet group received $1 \%$ cholesterol diet only, $\mathrm{HCD}+\mathrm{H}_{1}$ and $\mathrm{HCD}+\mathrm{H}_{2}$ groups received $1 \%$ cholesterol diet plus 0.3 and $0.6 \mathrm{~g} \mathrm{~kg}^{-1}$ dose of Trihoney, respectively, $\mathrm{HCD}+\mathrm{At}=$ group received $1 \%$ cholesterol diet plus $2 \mathrm{mg} \mathrm{kg}^{-1}$ dose of atorvastatin 
for development of atherosclerotic lesions and at the other end indicated the medical importance of lowering serum cholesterol and reducing expression of these inflammatory adhesion molecules. These findings are supported by Fotis et al. (2012) who correlated between expression of ICAM-1 in aorta and elevated serum soluble form in experimental animals fed high cholesterol diet and concluded the importance of serum
ICAM-1 as a reliable measure for ICAM-1 expression in the aortic wall. Another supporting study conducted by Mikail (2015) who investigated the antioxidant and cardioprotective effects of Baccaurea angulata fruit in hypercholesterolemic rabbits, in that study author demonstrated reduction of ICAM-1 and VCAM-1 in serum and in aortic tissue homogenate.

TABLE 5. Correlation between serum intercellular adhesion molecule ${ }^{-1}$ (ICAM-1), vascular cell adhesion molecule $^{-1}$ (VCAM-1), and serum lipid profile

\begin{tabular}{|c|c|c|}
\hline & $\mathrm{TC}\left(\mathrm{mmol} \mathrm{L}^{-1}\right)$ & LDL-c $\left(\mathrm{mmol} \mathrm{L}^{-1}\right)$ \\
\hline Serum Soluble ICAM-1 (ng mL $\left.{ }^{-1}\right)$ & $r=0.497^{* *}$ & $r=0.503^{* *}$ \\
\hline Serum Soluble VCAM-1 $\left(\mathrm{pg} \mathrm{mL} \mathrm{mL}^{-1}\right)$ & $r=0.393^{*}$ & $r=0.378^{*}$ \\
\hline
\end{tabular}

TABLE 6. Correlation between serum vascular cell adhesion molecule-1 (VCAM-1) and aortic lesion area percentage

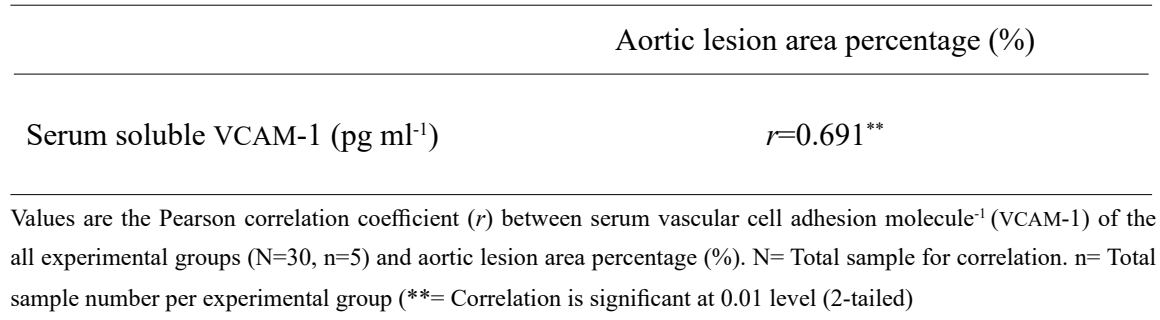

Previous studies showed that the lipid lowering effect of honey may be due to modulation of HMGCoA reductase enzyme through anti-oxidant effects, or may be due to vitamin $\mathrm{E}$ and prostaglandins contents of honey, in addition to other antioxidant properties (AlWaili et al. 2013). Since Trihoney has high total phenolic contents in addition to many phenolic compounds such as Quercetin, Kaempferol, Rutin, Catechin, Maleic acid, Caffeic acid, Cinnamic acid, Coumaric acid,
Gallic acid, p-Hydroxybenzoic acid, Salicylic acid, Sinapic acid, and Vanillic acid, in addition to high free radical scavenging activity (DPPH) and ferric reducing ability of plasma analysis (FRAP), therefore, the lipid lowering effect of Trihoney most likely attributed to its antioxidant function by which it modulates HMG-CoA reductase either directly or indirectly. Furthermore, Trihoney may exerted the reducing effect on the adhesion molecules most likely through the lipid lowering effect 
by which Trihoney reduced the serum LDL-c, the antiinflammatory function by which Trihoney suppressed the pro-atherogenic cytokines, the antioxidant effects by which Trihoney induced the endogenous antioxidant enzymes, ameliorated oxidative stress and markedly inhibited lipid peroxidation (Alfarisi et al. 2019). All these protective functions can contribute to the suppression of adhesion molecules (ICAM-1 and VCAM-1) and consequently may explain the anti-atherogenic effects of Trihoney against atherosclerosis. In this experiment, one experimental group was supplemented with atorvastatin in order to compare effects of Trihoney with this wellknown statin. Results showed by Trihoney were very comparable to those of atorvastatin in reducing serum ICAM-1. Atorvastatin showed a reducing effect also on VCAM-1 but Trihoney was more effective in terms of statistical significance. In accordance with the results of the current study, Du et al. (2013) who investigated hypercholesterolemic rabbit model and used exactly 2 $\mathrm{mg} \mathrm{kg}^{-1}$ day $^{-1}$ atorvastatin, reported significant reducing effect on ICAM-1 expression. In agreement with the results of the present study, statins have been shown to inhibit vascular expression of ICAM-1 and VCAM-1 by antagonism of some inflammatory cytokines such as TNF- $\alpha$ and IL-1 $\beta$ (Tousoulis et al. 2016). Moreover, statins found to have ability to modify intracellular inflammatory pathways such as decreasing production of isoprenoid intermediators that are responsible for the post-translational modification of small GTPases implicated in inflammatory response (Tousoulis et al. 2016). In overall, statins appeared to have pleiotropic effects on the pathogenesis of atherosclerosis independent of their lipid lowering function (Ray \& Cannon 2005). Despite that, the protective role of statins against atherosclerosis is still debatable. Trihoney may represent safe adjuvant remedy to statins for protection against atherosclerosis disregarding age or other comorbidities.

\section{CONCLUSION}

Trihoney has ability to reduce serum soluble adhesion molecules ICAM-1 and VCAM-1. Trihoney may be suggested as an adjuvant remedy to statins for management and protection against atherosclerosis.

\section{REFERENCES}

AEPC 2012. Kuantan: International Islamic University Malaysia Animal Ethics Policy.

Alfarisi, H.A.H., Ibrahim, M.B., Mohamed, Z.B.H., Hamdan, A.H.B. \& Mohamad, C.A.C. 2019. Trihoney ameliorates oxidative stress in atherosclerotic aorta. International Journal of Allied Health Sciences 3(3): 767-767.

Al-Waili, N., Salom, K., Al-Ghamdi, A., Ansari, M.J., Al-Waili, A. \& Al-Waili, T. 2013. Honey and cardiovascular risk factors, in normal individuals and in patients with diabetes mellitus or dyslipidemia. Journal of Medicinal Food 16(12): 1063-1078.

Bergheanu, S.C., Bodde, M.C. \& Jukema, J.W. 2017. Pathophysiology and treatment of atherosclerosis: Current view and future perspective on lipoprotein modification treatment. Netherlands Heart Journal 25(4): 231-242.

Boesten, L.S.M., Zadelaar, A.S.M., van Nieuwkoop, A., Gijbels, M.J., De Winther, M.P., Havekes, L.M. \& van Vlijmen, B.J. 2005. Tumor necrosis factor- $\alpha$ promotes atherosclerotic lesion progression in $\mathrm{APOE}^{*} 3$-leiden transgenic mice. Cardiovascular Research 66(1): 179-185.

Bolayirli, I.M., Aslan, M., Balci, H., Altug, T., Hacibekiroglu, M. \& Seven, A. 2007. Effects of atorvastatin therapy on hypercholesterolemic rabbits with respect to oxidative stress, nitric oxide pathway and homocysteine. Life Sciences 81(2): 121-127.

Brevetti, G., Schiano, V. \& Chiariello, M. 2006. Cellular adhesion molecules and peripheral arterial disease. Vascular Medicine 11(1): 39-47.

Brown, S. 2016. Taking Blood Sample from Rabbit. IDEXX Laboratory. pp. 1-11.

Catapano, A.L., Graham, I., De Backer, G., Wiklund, O., Chapman, M.J., Drexel, H., Hoes, A.W., Jennings, C.S., Landmesser, U., Pedersen, T.R. \& Reiner, Ž. 2016. 2016 ESC/ EAS guidelines for the management of dyslipidaemias: The task force for the management of dyslipidaemias of the european society of cardiology (ESC) and European Atherosclerosis Society (EAS) developed with the special contribution of the European Association for Cardiovascular Prevention \& Rehabilitation (EACPR). Atherosclerosis 253(2016): 281-344.

de Almeida Torres, R.J., Noronha, L.D., de Almeida Torres, R.D.R., Nagashima, S., de Almeida Torres, C.L., Luchini, A., de Almeida Torres, R.A., Précoma, L.B. \& Précoma, D.B. 2014. Increased intercellular adhesion molecule-1 immunoreactivity in the sclera-choroid complex in hypercholesterolemia experimental model. Revista Brasileira de Oftalmologia 73(4): 210-215.

Du, B., Xu, G., Cao, H., Cui, W., Lin, S., Liu, Y. \& Qin, L. 2013. Effects of atorvastatin on expression of ICAM-1 in atherosclerotic rabbits. Journal of Cardiovascular Medicine 14(2): 120-126.

Fan, J., Shimoyamada, H., Sun, H., Marcovina, S., Honda, K. \& Watanabe, T. 2001. Transgenic rabbits expressing human apolipoprotein(a) develop more extensive atherosclerotic lesions in response to a cholesterol-rich diet. Arteriosclerosis, Thrombosis, and Vascular Biology 21(1): 88-94.

Fotis, L., Agrogiannis, G., Vlachos, I.S., Pantopoulou, A., Margoni, A., Kostaki, M., Verikokos, C., Tzivras, D., Mikhailidis, D.P. \& Perrea, D. 2012. Intercellular adhesion molecule (ICAM)-1 and vascular cell adhesion molecule (VCAM)-1 at the early stages of atherosclerosis in a rat model. In vivo 26(2): 243-250.

Friedewald, W.T., Levy, R.I. \& Fredrickson, D.S. 1972. Estimation of the concentration of low-density lipoprotein cholesterol in plasma, without use of the preparative ultracentrifuge. Clinical Chemistry 18(6): 499-502. 
Hansson, G.K. 2005. Inflammation, atherosclerosis, and coronary artery disease. New England Journal of Medicine 352(16): 1685-1695.

Hope, S.A. \& Meredith, I.T. 2003. Cellular adhesion molecules and cardiovascular disease. Part I. Their expression and role in atherogenesis. Internal Medicine Journal 33(8): 380-386.

Ibrahim, M., Ahmed, I.A., Mikail, M.A., Ishola, A.A., Draman, S., Isa, M.L.M. \& Yusof, A.M. 2017. Baccaurea angulata fruit juice reduces atherosclerotic lesions in diet-induced hypercholesterolemic rabbits. Lipids in Health and Disease 16(1): $1-8$

Jellinger, P.S., Handelsman, Y., Rosenblit, P.D., Bloomgarden, Z.T., Fonseca, V.A., Garber, A.J., Grunberger, G., Guerin, C.K., Bell, D.S., Mechanick, J.I. \& Pessah-Pollack, R. 2017. American Association of Clinical Endocrinologists and American College of Endocrinology guidelines for management of dyslipidemia and prevention of cardiovascular disease. Endocrine Practice 23(2): 1-87.

Jorge, P.A.R., Almeida, E.A.D., Ozaki, M.R., Jorge, M. \& Carneiro, A. 2005. Effects of atorvastatin, fluvastatin, pravastatin, and simvastatin on endothelial function, lipid peroxidation, and aortic atherosclerosis in hypercholesterolemic rabbits. Arquivos Brasileiros de Cardiologia 84(4): 314-319.

Kong, L., Luo, C., Li, X., Zhou, Y. \& He, H. 2013. The antiinflammatory effect of kaempferol on early atherosclerosis in high cholesterol fed rabbits. Lipids in Health and Disease 12(1): 1-12.

Li, H., Cybulsky, M.I., Gimbrone Jr., M.A. \& Libby, P. 1993. An atherogenic diet rapidly induces VCAM-1, a cytokineregulatable mononuclear leukocyte adhesion molecule, in rabbit aortic endothelium. Arteriosclerosis and Thrombosis: A Journal of Vascular Biology 13(2): 197-204.

Lorkowski, S. \& Cullen, P. 2007. Atherosclerosis: Pathogenesis, clinical features \& treatment. Encyclopedia of Life Sciences. pp. 1-11.

Majtanova, N., Cernak, M. \& Majtan, J. 2016. Honey: A natural remedy for eye diseases. Forschende Komplementarmed 23(6): $1-6$

Mikail, M.A. 2015. In vivo antioxidant potential and cardioprotective activities of Baccaurea angulata fruit in relation to suppressed inflammatory response. Doctoral dissertation, Kulliyyah of Allied Health Sciences, International Islamic University Malaysia (Unpublished).

Mohanta, S., Yin, C., Weber, C., Hu, D. \& Habenicht, A. 2016. aorta atherosclerosis lesion analysis in hyperlipidemic mice. Bio-Protocol 6(11): 1-15.

Moore, K.J. \& Tabas, I. 2011. The cellular biology of macrophages in atherosclerosis. Cell 145(3): 341-355.

Ohta, H., Wada, H., Niwa, T., Kirii, H., Iwamoto, N., Fujii, H., Saito, K., Sekikawa, K. \& Seishima, M., 2005. Disruption of tumor necrosis factor- $\alpha$ gene diminishes the development of atherosclerosis in ApoE-deficient mice. Atherosclerosis 180(1): 11-17.

Oikonomou, E., Latsios, G., Vogiatzi, G. \& Tousoulis, D., 2017. Atherosclerotic plaque. In Coronary Artery Disease: From Biology to Clinical Practice. Massachusetts: Academic Press. pp. 31-41.

Patel, K.M., Strong, A., Tohyama, J., Jin, X., Morales, C.R., Billheimer, J., Millar, J., Kruth, H. \& Rader, D.J. 2015.
Macrophage sortilin promotes LDL uptake, foam cell formation, and atherosclerosis. Circulation Research 116(5): 789-796.

Rahman, A.R.A., Suhaimi, A., Meow, C.K., Mustapha, F.I., Mohamad, M., Salleh, N.A. \& Ahmad, W.A.W. 2017. Clinical Practice Guideline: Primary \& Secondary Prevention of Cardiovascular Disease 2017. Putrajaya: Ministry of Health, Malaysia.

Randolph, G.J. 2014. Mechanisms that regulate macrophage burden in atherosclerosis. Circulation Research 114(11): $1757-1771$

Ray, K.K. \& Cannon, C.P. 2005. The potential relevance of the multiple lipid-independent (Pleiotropic) effects of statins in the management of acute coronary syndromes. Journal of the American College of Cardiology 46(8): 1425-1433.

Reagan-Shaw, S., Nihal, M. \& Ahmad, N. 2007. Dose translation from animal to human studies revisited. The FASEB Journal 22(3): 659-661.

Song, X., Liu, H., Wang, X., Li, Z. \& Huang, C. 2014. Atorvastatin combined with poly-unsaturated fatty acid confers better improvement of dyslipidemia and endothelium function. Lipids in Health and Disease 13(1): 1-5.

Spilioti, E., Jaakkola, M., Tolonen, T., Lipponen, M., Virtanen, V., Chinou, I., Kassi, E., Karabournioti, S. \& Moutsatsou, P. 2014. Phenolic acid composition, antiatherogenic and anticancer potential of honeys derived from various regions in Greece. PloS ONE 9(4): e94860.

Sukardi, S., Yaakub, H., Ganabadi, S. \& Poon, M.S. 2005. Serum testosterone levels and body weight gain of male rabbits fed with Morinda citrifolia fruit juice. Malaysian Journal of Nutrition 11(1): 59-68.

Thon, C.C., Yein, L.P. \& Lian, C.W. 2012. The prevalence of cardiovascular risk factors in the young and middle-aged rural population in Sarawak, Malaysia. The Malaysian Journal of Medical Sciences 19(2): 27-34.

Tousoulis, D., Oikonomou, E., Economou, E.K., Crea, F. \& Kaski, J.C. 2016. Inflammatory cytokines in atherosclerosis: Current therapeutic approaches. European Heart Journal 37(22): 1723-1732.

Tousoulis, D., Daves, G.J., Asimakopoulos, G., Homaei, H., Zouridakis, E., Ahmed, N. \& Kaski, J.C. 2001. Vascular cell adhesion molecule-1 and intercellular adhesion molecule-1 serum level in patients with chest pain and normal coronary arteries (syndrome X). Clinical Cardiology 24(4): 301-304

Wu, M.Y., Li, C.J., Hou, M.F. \& Chu, P.Y. 2017. New insights into the role of inflammation in the pathogenesis of atherosclerosis. International Journal of Molecular Sciences 18(10): 2034-2052.

Yu, Q., Li, Y., Waqar, A.B., Wang, Y., Huang, B., Chen, Y., Zhao, S., Yang, P., Fan, J. \& Liu, E. 2012. Temporal and quantitative analysis of atherosclerotic lesions in dietinduced hypercholesterolemic rabbits. BioMed Research International 2012: Article ID. 506159.

Zhou, G., Ge, S., Liu, D., Xu, G., Zhang, R., Yin, Q., Zhu, W., Chen, J. \& Liu, X. 2010. Atorvastatin reduces plaque vulnerability in an atherosclerotic rabbit model by altering the 5-lipoxygenase pathway. Cardiology 115(3): 221-228.

Hamad Abdulsalam Hamad Alfarisi, Muhammad Ibrahim* \&

Zenab b. Hamad Mohamed 
Department of Nutrition Sciences

Kulliyyah of Allied Health Sciences

International Islamic University Malaysia

25200 Kuantan, Pahang Darul Makmur

Malaysia

Asmah Hanim Hamdan

Department of Pathology \& Laboratory Medicine

Kulliyyah of Medicine

International Islamic University Malaysia

25200 Kuantan, Pahang Darul Makmur

Malaysia
Che Anuar Che Mohamad

Department of Basic Medical Sciences

Kulliyyah of Pharmacy

International Islamic University Malaysia

25200 Kuantan, Pahang Darul Makmur

Malaysia

*Corresponding author; email: abumaisarah@iium.edu.my

Received: 21 December 2019

Accepted: 9 March 2020 